\title{
Tillage Method and Residual N, P, K, Zn, B, Mg, Ca, and S Nutrients Effect on Growth and Yield of Dry Bean Grown after the Harvest of Maize
}

\author{
Hillary M. O. Otieno ${ }^{1,4, a, *}$, George N. Chemining'wa ${ }^{1, b}$, Shamie Zingore ${ }^{2, c}$, Charles K. Gachene ${ }^{3, d}$ \\ ${ }^{I}$ Department of Plant Science and Crop Protection, University of Nairobi, Nairobi, Kenya \\ ${ }^{2}$ International Plant Nutrition Institute, Sub-Saharan Africa Program, Nairobi, Kenya \\ ${ }^{3}$ Department of Land Resource Management and Agricultural Technology, University of Nairobi, Nairobi, Kenya \\ ${ }^{4}$ Department of Agricultural Research, One Acre Fund, Nairobi, Kenya
}

*Corresponding author

\begin{tabular}{|c|c|}
\hline A R T I C L E INFO & A B S T R A C T \\
\hline $\begin{array}{l}\text { Keywords: } \\
\text { Conservation agriculture } \\
\text { Dry bean } \\
\text { No-till } \\
\text { Residual fertilizer } \\
\text { Soil water conservation. }\end{array}$ & $\begin{array}{l}\text { Common bean (Phaseolus vulgaris L.) production is constrained majorly by drought and low soil } \\
\text { fertility in Kenya. These limitations have never been adequately approached due to financial } \\
\text { challenges and lack of better technology. A study was carried out in Kirinyaga and Embu Counties } \\
\text { to evaluate the effects of tillage method and residual fertilizers on yield performance of dry bean. } \\
\text { Dry bean was grown in the short rains season on plots preceded by fertilized maize (Zea mays L.) } \\
\text { grown in the long rains season. The trials were laid out in a randomized complete block design with } \\
\text { a split-plot arrangement. The tillage methods, NT+CR and CT-CR, where NT: No-tillage, CT: } \\
\text { Conventional tillage, and CR: Crop residue, were assigned the main plot and residual fertilizers (NK, } \\
\text { NP, PK, NPK, and NPK+CaMgZnBS) the subplots. The results showed that there was } 35 \% \text { and } 46 \% \\
\text { more water retention under NT+CR than under CT-CR system in Embu and Kirinyaga sites, } \\
\text { respectively. NT+CR produced higher biomass, more number of pods per plant, number of seeds per } \\
\text { pod, and } 1000 \text {-seed weight. Plots with residual NPK+ZnBMgCaS yielded higher biomass at } 60 \\
\text { DAE, number of seeds per pod, } 1000 \text {-seed weight and grain yield than plots with other treatments. } \\
\text { The residual NPK+ZnBMgCaS and NPK treatments out yielded PK treatment by } 600 \mathrm{~kg} \text { ha }{ }^{-1} \text { and } \\
370 \mathrm{~kg} \text { ha }{ }^{-1} \text { (Embu) and by } 710 \mathrm{~kg} \text { ha }{ }^{-1} \text { and } 330 \mathrm{~kg} \text { ha }{ }^{-1} \text { (Kirinyaga), respectively. Based on these } \\
\text { results, cultivation of dry bean on residual fertilizer nutrients solely or in combination with no-till } \\
\text { and crop residue retention after maize harvest has the potential to improve the yields and food } \\
\text { security among farmers in the region. }\end{array}$ \\
\hline
\end{tabular}

hillarymoses.otieno@gmail.com (iD) https://orcid.org/0000-0003-4659-9568

\section{Introduction}

Dry bean (Phaseolus vulgaris L.) is one of the most important food legume crops in Kenya. It is cultivated by over $85 \%$ of farming households in Kenya (Otieno et al., 2019) mostly due to its cheap source of cholesterol-free proteins and fast maturity (Voisin et al., 2014). The crop offers the best alternative source of daily-recommended level of iron, rich source of complex carbohydrates and dietary fibre (Labarta, 2013). Dry bean also serves as an alternative source of cash in case of surplus that enables farmers to meet their farm needs (Otieno et al., 2019). In a cropping system, dry bean rotation has several potential agronomic benefits. The system helps in soil water conservation, minimization of salinity problems in arid and semi-arid lands and weed management (Liebman et al. 1996; Turner, 2004).
Despite these benefits, dry bean yields are still low at less than $1 \mathrm{t} \mathrm{ha}^{-1}$ (Monyo et al., 2013). This is mainly due to low soil fertility and drought across major bean producing zones in Kenya (Abate et al., 2012; Otieno et al., 2018; Otieno et al., 2019). The impacts of these constraints are aggravated further by lack of adoption of best practices capable of conserving and improving efficient usage of already limiting soil moisture and nutrients by small scale farmers who are the major producers in the region. Typical dry bean production in Kenya involves the use of no fertilizers, a practice that greatly increases nutrient mining from the soil. Again, over-reliance on N-P based fertilizers for maize (Zea mays L.) production has led to unbalanced soil nutrients supply and further mining of other nutrients like $\mathrm{K}, \mathrm{S}, \mathrm{Ca}, \mathrm{Mg}, \mathrm{Zn}$, and $\mathrm{B}$ from the soil. This is despite 
important contributions of $\mathrm{K}, \mathrm{S}, \mathrm{Ca}, \mathrm{Mg}, \mathrm{Zn}$, and $\mathrm{B}$ nutrients in plant growth and production (Fageria and Gheyi, 1999; Zeidan et al., 2006; Machado et al., 2008; Fageria, 2014). This situation is aggravated further by lack of better soil conservation practices such as crop residues retention and reduced tillage leaving no chance for the build-up of soil nutrients in the region.

Erratic and frequent droughts during the production seasons further hinder dry bean growth and yields. The use of irrigation technology to supplement low rainfall is not possible due to inadequate financial capacity to buy, install and maintain irrigation system by farmers (Otieno et al., 2019). As conventionally practiced in the region, production of common bean is done during the short rain seasons with high rainfall variability leading high chances of crop failure due to low water stress. The current conventional tillage method coupled with the burning and removal of crop residues from the fields further results in great soil water and nutrients loss. This is because these practices destabilize soil structure and expose already limited soil moisture to a greater degree of losses through evapotranspiration (Gowing and Palmer, 2008).

Averting the current situation calls for the adoption of a new and sustainable system characterized by no-tillage, crop residue retention, and use of residual nutrients in Kenya. This combination is likely to create synergy and result in a sustainable system with better soil water and nutrient management than tilling of land with no crop residue retention as currently practiced by farmers. Combination of crop residue retention with no-tilling of fields has been found to increase soil aggregation, increase water infiltration and conserve soil water and nutrients for better crop yields (Marongwe et al., 2011; Giller et al., 2011; Kihara et al., 2011; Otieno et al., 2019). The buildup of crop residue over time could provide a thick layer of mulch that helps in weed control and reduce water loss through evapotranspiration (Hobbs et al., 2008). Depending on the quality of the crop residue, decomposition of these materials could release nutrients for use by the subsequent crops. For instance, under conservation and conventional tillage systems, highquality bean residue was found to release nutrients more quickly than more fibrous cereal residues upon putrefaction (Lu et al., 2011). Also, production of dry bean after fertilized maize could ensure that the crops benefit from the residual nutrients left after harvesting. This could ensure increased efficiency in the use of applied nutrient resources as the remnants are put into use for bean production. The practice is likely to reduce the demand for fresh fertilizer applications during bean production thereby reducing the cost of bean production.

This kind of system has never been consciously investigated in Kenya for sustainable dry bean production despite the increasing cost of fertilizers in the country. Again, the use of a wide range of nutrients on beans has never been investigated across major producing zones as most farmers use NP-based fertilizers for production leading to high mining of other nutrients such as $\mathrm{K}, \mathrm{S}, \mathrm{Ca}$, $\mathrm{Mg}, \mathrm{Zn}$, and $\mathrm{B}$. This study was, therefore, conducted to evaluate the effect of tillage method and residual fertilizer nutrients on dry bean biomass and yield.

\section{Materials and Methods}

\section{Site Description}

The trials were carried out in Kirinyaga (37 $17^{\circ} 10.4^{\prime \prime} \mathrm{E}$ and $\left.00^{\circ} 30^{\prime} 18.3^{\prime \prime} \mathrm{S}\right)$ and Embu (37 19' 10.4"E and latitude $00^{\circ} 33^{\prime} 29.4^{\prime \prime}$ ) Counties from 2013 to 2014/2015 cropping season. The soil type in these study sites was Humic Nitisols, which are deep, well-weathered and have moderate to high acidity with inherent high phosphorus fixing capacity (Jaetzold et al., 2006). The two sites are located in the upper midland zones with a bi-modal rainfall pattern, experiencing wet seasons from March to May (long rains) and September to December (short rains) with an annual rainfall range of $1100 \mathrm{~mm}$ to $1550 \mathrm{~mm}$. The daily mean temperature is about $18^{\circ} \mathrm{C}$ in Embu and $23^{\circ} \mathrm{C}$ in Kirinyaga. Other soil characteristics are as shown in Table 1.

Table 1. Baseline soil fertility characteristics of the experimental sites.

\begin{tabular}{l|rc}
\hline \multicolumn{1}{c|}{ Parameter } & Embu & Kirinyaga \\
\hline $\mathrm{pH}$ & 4.44 & 5.95 \\
Total soil organic carbon (\%) & 2.00 & 2.56 \\
Total nitrogen (\%) & 0.21 & 0.28 \\
Extractable potassium (me \%) & 0.28 & 0.24 \\
Phosphorus (ppm) & 37.80 & 44.90 \\
Calcium (me \%) & 1.60 & 1.70 \\
Magnesium (me \%) & 5.20 & 7.46 \\
Zinc (ppm) & 18.80 & 10.30 \\
\hline
\end{tabular}

\section{Experimental Design and Treatments}

The trials were laid out in a randomized complete block design with a split-plot arrangement. Each treatment was replicated three times with each experimental plot measuring $8 \mathrm{~m}$ by $10 \mathrm{~m}$. A path of $1.5 \mathrm{~m}$ and $1 \mathrm{~m}$ wide was left between blocks and plots, respectively. The tillage method was assigned to the main plots and residual fertilizer nutrients assigned to subplots. The tillage methods were conservation agriculture that combines no tilling of land with retention of crop residue (NT+CR) and conventional tillage involving tilling of land with complete removal of crop residue (CT-CR): NT: No-tillage, CT: Conventional tillage, CR: Crop residue. Five inorganic fertilizer nutrient combinations (NK, NP, PK, NPK, and $\mathrm{NPK}+\mathrm{CaMgZnBS}$ ) were assigned to the subplots. All plots were marked and planted with maize without any fertilizer application during the 2013 short rains season. This was done to provide crop residue for the CT+CR plots and deplete soil nutrients that would otherwise cause huge variations during the main experiment in all plots. During 2014 long rains season, all subplots were supplied with N, $\mathrm{P}, \mathrm{K}, \mathrm{Ca}, \mathrm{Mg}, \mathrm{Zn}, \mathrm{B}$ and $\mathrm{S}$ nutrients at the rate of 120,40 , $40,10,10,5$ and $26.3 \mathrm{~kg} \mathrm{ha}^{-1}$, from urea, triple superphosphate (TSP), muriate of potash (MOP), calcium sulphate, magnesium sulphate, zinc sulphate and borax sources, respectively (Otieno et al., 2019). Maize DK 8031 variety was used for trial because of its high popularity and adaptation to the prevailing climatic conditions. After harvesting maize, dry beans were planted during 2014/2015 short rains season without any fertilizer application. 


\section{Common Bean Agronomic Practices}

Land preparation was done in October 2014 before onset of the short rains. The CT-CR plots were prepared through conventional tilling using local hand-hoe farm implements and crop residues removed completely. Both $\mathrm{NT}+\mathrm{CR}$ and CT-CR plots were planted at the onset of short rains at a seed rate of $50 \mathrm{~kg} \mathrm{ha}^{-1}$ and spacing of $50 \mathrm{~cm}$ by $15 \mathrm{~cm}$. Two seeds were planted per hill. Two days after planting, NT+CR plots were sprayed with a mixture of Dual Gold 960EC (active ingredient: S-metolachlor.) and Weedal 480SL (active ingredient: Glyphosate) herbicides at a rate of $1.51 \mathrm{ha}^{-1}$ each to kill the perennial and already germinating weeds. To ensure the safety of the applicator during herbicide application, full personal protective equipment (overall, gumboots, breathing mask, gloves, and eye goggles) was used and other best practices followed as described by Otieno (2019). Weeding was done twice by hand on conventional tillage system plots whereas Basagran (active ingredient: Bentazon) herbicide at 1.51 $\mathrm{ha}^{-1}$ was used to control weeds on no-till system plots. Few perennial weeds that were not controlled using this herbicide were mechanically controlled by hand uprooting. This experiment was carried out purely under rain-fed conditions.

\section{Data Collection}

Data collection was done at various stages: Soil moisture conservation at 30 and 60 days after emergence (DAE); biomass production during growth at 60 DAE; nematode infection at grain setting; and yield attributes and grain yield at harvesting.

Soil moisture retention: At 30 and 60 DAE, 5 soil samples were randomly taken at $0-30 \mathrm{~cm}$ depth from each replicate. Fresh soil weights were taken right at the field then the samples dried at 105 degrees Celsius $\left({ }^{0} \mathrm{C}\right)$ to a constant weight in the laboratory. The differences between the fresh and dry weights of the samples were averaged and used to calculate the soil water retention according to Klute (1986).

Biomass production: At 60 DAE, above-ground biomass assessment was carried out from a $20 \mathrm{~m}^{2}$ net plot for all treatment replicates across the sites. During the process, plants were cut at the ground level and their fresh weights recorded. A subsample containing both stalks and leaves of $500 \mathrm{~g}$ fresh weight was taken for all plots and oven-dried at $65{ }^{\circ} \mathrm{C}$ to a constant weight. Both fresh and dry samples were used to determine the proportion of dry matter following procedures outlined by Otieno et al. (2018).

Nematode infestation: At the pod filling stage, 20 bean plants in each replicate were pulled out, roots washed and used to assess the percentage of nematode infection. The percentage infection was then scaled based on the college of agricultural and veterinary sciences, University of Nairobi, nematology laboratory chart.

Stover and yield: At two weeks after physiological maturity, a net plot area of $20 \mathrm{~m}^{2}$ was used to collect all other harvest parameters. After taking total plant count, the number of pods per plant and number of seeds per pod was determined by randomly sampling 20 plants and 20 pods, respectively. The 1000-seed weight was computed from dried grains by manually picking 1000 seeds at random and weighing using an electronic balance. After threshing, stover yield (stems, stalks and empty pods of bean) was calculated from a $500 \mathrm{~g}$ subsample dried to a constant weight at $65{ }^{0} \mathrm{C}$. Grain production per hectare was computed from yield components using Fagaria (2009) formula. Harvest Index (HI) of dry bean was determined using the ratio of dried grain yield to the total aboveground dry matter. Grain to stover ratio was calculated by dividing the total grain per hectare by the total stover per hectare produced for every treatment.

\section{Data Analysis}

All collected data were entered in Excel Computer Package. For each of the parameters considered, data were subjected to analysis of variance (ANOVA) using Genstat Software $15^{\text {th }}$ Edition statistical package. The means were separated using Fisher's protected least-significant difference (L.S.D.) test at $P \leq 0.05$.

\section{Results}

\section{General Observations}

Rainfall and nematode infection

Rainfall was generally low with several days going dry (Figure 1). Planting and emergence of crops occurred under very low rainfall (weeks 1 and 2) (Figure 1). Small amounts of rainfall were received during the midvegetative stage (week 3). Rainfall reduced immediately when crops were getting to the initial reproductive stage (flower bud initiation) at the $6^{\text {th }}$ week and continued to decline until the $8^{\text {th }}$ week. It then increased sharply into the $9^{\text {th }}$ week and then declined for the rest of the production period. Root gall nematode infestation was also visually observed during plant growth. The incidence level ranged between 3 and 4 (38 to 63\% roots galled) under conventional tillage (CT-CR) compared to 2 and 3 (23 to $38 \%$ roots galled) under conservation agriculture $(\mathrm{NT}+\mathrm{CR})-$ the data is not given because it is not the main focus point.

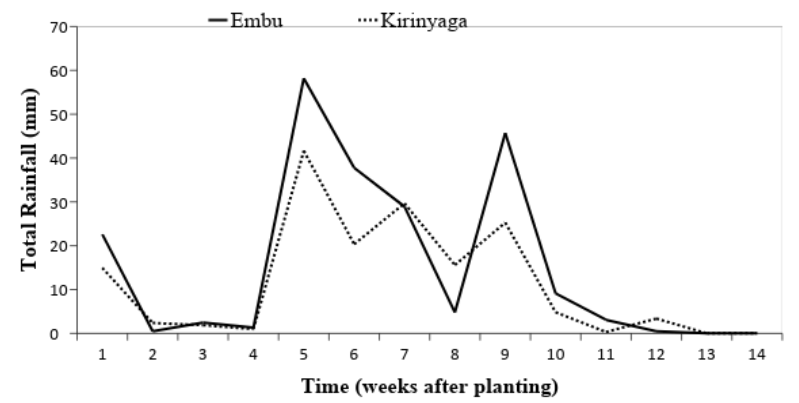

Figure 1. Rainfall distribution and amounts during dry bean production. Source: KALRO-Embu and Kirinyaga Coffee Estate rainfall stations

Change in soil fertility status after maize production

After a year of trial, the changes in soil chemical properties were observed to vary across the sites (Figure 2). In Embu site, soil pH, SOC, N, P, K, and Ca levels improved compared to the baseline condition. The increases were by $3.8,0.5,19,57.1,184.6$ and $48.1 \%$, respectively. However, $\mathrm{Mg}$ and $\mathrm{Zn}$ levels reduced by 78.8 and $11.3 \%$, respectively. In Kirinyaga site, soils increased in acidity by $12 \%$. Soil total $\mathrm{N}, \mathrm{Mg}$ and $\mathrm{Zn}$ nutrient levels also dropped by 7, 50 and $46 \%$, respectively. 


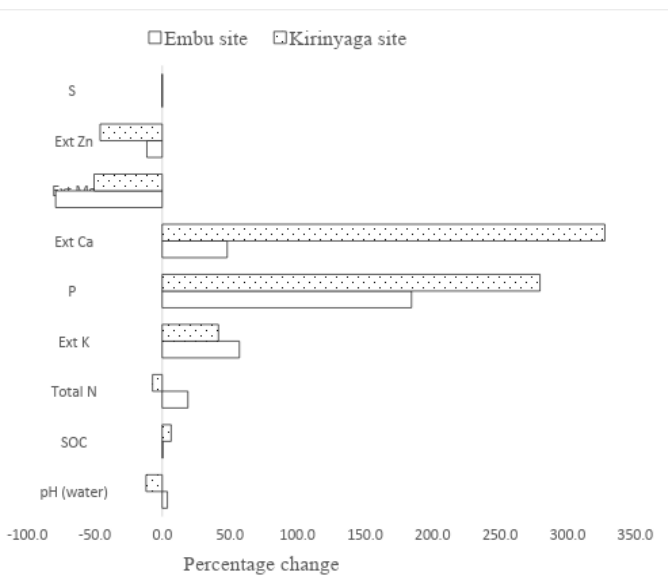

Figure 2. Percentage change in the soil fertility status after a year of the trial. This percentage change is between baseline soil fertility status and soil fertility status at the time of bean planting.
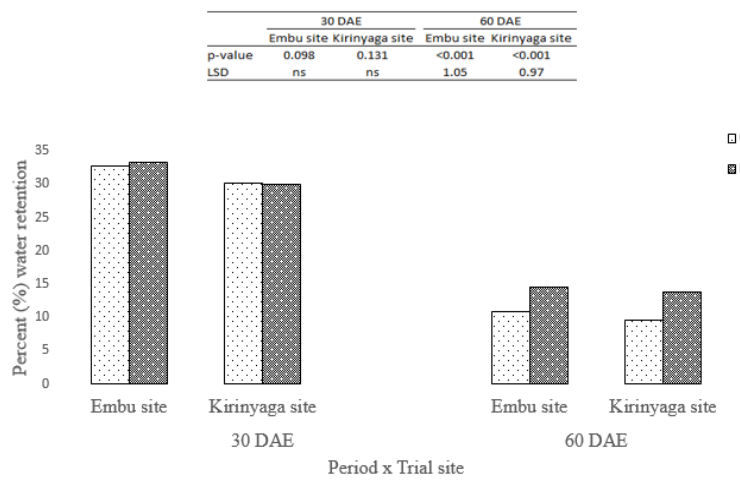

Figure 3. Percentage soil moisture retention as influenced by tillage methods at Embu and Kirinyaga sites at 30 and 60 days after emergence during 2014/2015 short rains season of dry bean production.

DAE $=$ Days after emergence; NT+CR $=$ No-till with crop residues retention; CT-CR = conventional tillage with no crop residues retention; $\mathrm{NT}=$ No-tillage $; \mathrm{CT}=$ Conventional tillage $; \mathrm{CR}=$ Crop residue, $\mathrm{ns}=$ Not significant

Effect of Tillage Method on Soil Moisture Retention

Tillage method significantly influenced the amount of soil water retained at both Embu and Kirinyaga sites at 60 days after emergence (DAE) (Figure 3). Embu site consistently recorded high soil water levels compared to Kirinyaga site. The NT+CR system was superior resulting in $35 \%$ and $46 \%$ more water retention than CT-CR system in Embu and Kirinyaga sites, respectively.

Effect of Tillage Method and Residual Fertilizer On Shoot Biomass Production

Conservation agriculture (NT+CR) influenced shoot biomass at $60 \mathrm{DAE}$ and stover at harvesting (Table 2). The NT+CR system had significantly higher shoot biomass at 60 DAE than CTR-CR in Kirinyaga site (Table 2). At harvesting, the same tillage system produced $310 \mathrm{~kg} \mathrm{ha}^{-1}$ and $170 \mathrm{~kg} \mathrm{ha}^{-1}$ more stover weight than CT-CR tillage system in Embu and Kirinyaga respectively. Tillage systems resulted in biomass weights that varied between 2.54 and $3.15 \mathrm{t} \mathrm{ha}^{-1}$ at $60 \mathrm{DAE}$ and 1.39 and $1.70 \mathrm{t} \mathrm{ha}^{-1}$ at harvesting (Table 2).

The effect of residual fertilizers was significant across all periods considered and trials sites. Residual PK fertilizer recorded lowest biomass compared to other residual fertilizers at both trials sites (Table 2). This residual fertilizer yielded significantly lower shoot biomass at $60 \mathrm{DAE}$ than NPK and $\mathrm{NPK}+\mathrm{ZnBMgCaS}$ (Table 2). Both residual NPK and $\mathrm{NPK}+\mathrm{ZnBMgCaS}$ produced significantly higher biomass and stover yields than residual PK fertilizers. These differences were $780 \mathrm{~kg}$ $\mathrm{ha}^{-1}$ and $1430 \mathrm{~kg} \mathrm{ha}^{-1}$ in Embu and $450 \mathrm{~kg} \mathrm{ha}^{-1}$ and $850 \mathrm{~kg}$ $\mathrm{ha}^{-1}$ in Kirinyaga at $60 \mathrm{DAE}$ period and $350 \mathrm{~kg} \mathrm{ha}^{-1}$ and 410 $\mathrm{kg} \mathrm{ha}^{-1}$ in Embu and $190 \mathrm{~kg} \mathrm{ha}^{-1}$ and $530 \mathrm{~kg} \mathrm{ha}^{-1}$ in Embu at harvesting stage respectively. The interaction between tillage method and residual fertilizer had no significant effect on biomass at $60 \mathrm{DAE}$ and stover dry weights at harvesting in both sites.

Effect of Tillage Method and Residual Fertilizer on Number of Pods Per Plant

The tillage method and residual fertilizer treatments significantly influenced the number of pod per plant in both sites (Table 3). No significant differences were observed among NP, PK, and NPK treatments and between NK and NP treatment in the number of pods produced per plant in both sites. The $\mathrm{NPK}+\mathrm{ZnBMgCaS}$ treatment resulted in 3.67 and 5.17 more pods per bean plant than NK treatment in Embu and Kirinyaga, respectively (Table 3). The effects of residual fertilizers across the sites on the number pods per plant were in the order of $\mathrm{NPK}+\mathrm{ZnBMgCaS}>\mathrm{NPK}>$ $\mathrm{PK}>\mathrm{NP}>\mathrm{NK}$. There was no significant interactive effect of tillage method and residual fertilizers on the number of pods per plant in both sites. The pods per plant varied from 12.00 to 15.67 in Embu and 10.83 to 16.00 in Kirinyaga. The NT+CR system yielded significantly higher number of pods per bean plant than CT-CR system in both sites. The average number of pods was 12.74 and 14.30 per plant in Kirinyaga and Embu, respectively (Table 3). The tillage method and residual fertilizer treatments significantly affected the number of seeds produced per pod in Embu (Table 3). The NT+CR tillage produced a higher number of seeds per pod than CT-CR system. Significantly lower number of seed per pod (3.84) was recorded in PK plots in Embu site. Treatment NPK+ZnBMgCaS had 0.99 and 0.50 higher number of seeds per pod than treatments PK and NK, respectively. No significant differences were noted among NK, NP and NPK treatments and among $\mathrm{NPK}+\mathrm{ZnBMgCaS}, \mathrm{NPK}$, and NP treatments. The average number of seeds per pod varied from 3.84 to 4.83 in Embu and 4.83 to 5.00 in Kirinyaga. The number of seeds per pod was in descending order of $\mathrm{NPK}+\mathrm{ZnBMgCaS}>\mathrm{NPK}>$ NP> NK> PK in both sites (Table 3). The interactive effect of tillage method and residual fertilizer was not significant in both sites.

Effect of Tillage Method and Residual Fertilizer on 1000-Seed Weight and Grain Yield

The tillage method significantly influenced 1000-seed weight in Embu but had no effect on this parameter in Kirinyaga (Table 4). In Embu, NT+CR system recorded a higher 1000-seed weight than CT-CR system. Residual fertilizers had significant effect on the 1000-seed weight in both sites. The lowest 1000-seed weight was recorded on PK residual plots in both sites. No differences were recorded among PK, NK, NP and NPK treatments in Embu and between PK and NK treatments in Kirinyaga. Residual 
$\mathrm{NPK}+\mathrm{ZnBMgCaS}$ fertilizer treatment had a higher 1000 seed weight than residual PK, NK and NP treatments in Embu and PK residual treatment in Kirinyaga. In Kirinyaga, $\mathrm{NPK}+\mathrm{ZnBMgCaS}, \mathrm{NPK}$, and NP residual fertilizer treatments were similar in 1000-seed weight. The average 1000-seed weight ranged from $299.5 \mathrm{~g}$ (Kirinyaga) to $346.5 \mathrm{~g}$ (Embu) (Table 4). No significant interaction was noted between tillage method and residual fertilizer nutrients with respect to 1000 -seed weight in both sites. Dry bean plants grown under NT+CR plots significantly out-yielded those under CT-CR plots by $140 \mathrm{~kg} \mathrm{ha}^{-1}$ and $200 \mathrm{~kg} \mathrm{ha}^{-1}$ in Kirinyaga and Embu trial sites, respectively (Table 4). Residual fertilizer had significant effects on dry bean grain yield in both sites. The $\mathrm{NPK}+\mathrm{ZnBMgCaS}$ treatment had significantly higher grain yield than all the other treatments. In Embu, NPK had significantly higher grain yield than NK and PK. The NPK $+\mathrm{ZnBMgCaS}$ and NPK treatments significantly out-yielded PK treatment by $600 \mathrm{~kg} \mathrm{ha}^{-1}$ and $370 \mathrm{~kg} \mathrm{ha}^{-1}$, respectively, in Embu. The PK, NP and NK treatments were not significantly different in grain yield. In Kirinyaga, NPK significantly out-yielded NK, NP and PK treatments. There were no significant grain yield differences between NK and NP treatments and between $\mathrm{NK}$ and PK treatments. The $\mathrm{NPK}+\mathrm{ZnBMgCaS}$ and NPK treatments out-yielded PK treatment by $710 \mathrm{~kg}$ $\mathrm{ha}^{-1}$ and $330 \mathrm{~kg} \mathrm{ha}^{-1}$, respectively (Table 4). The interaction between tillage method and residual fertilizer was not significant for grain yield in both sites. In both sites, grain yields varied from $1.14 \mathrm{t} \mathrm{ha}^{-1}$ (Kirinyaga) to $1.49 \mathrm{t} \mathrm{ha}^{-1}$ (Embu).

Table 2. Common bean biomass at 60 days after emergence (DAE) and stover at harvesting as influenced by tillage methods and residual fertilizers at Embu and Kirinyaga trial sites during 2014/2015 short rains season.

\begin{tabular}{|c|c|c|c|c|}
\hline \multirow{2}{*}{ Treatment } & \multicolumn{2}{|c|}{ Biomass at 60 DAE $\left(\mathrm{t} \mathrm{ha}^{-1}\right)$} & \multicolumn{2}{|c|}{ Stover $\left(\mathrm{t} \mathrm{ha}^{-1}\right)$} \\
\hline & Embu site & Kirinyaga site & Embu site & Kirinyaga site \\
\hline \multicolumn{5}{|c|}{ Tillage method } \\
\hline $\mathrm{NT}+\mathrm{CR}$ & 3.15 & 2.62 & 1.70 & 1.57 \\
\hline CT-CR & 2.95 & 2.54 & 1.39 & 1.40 \\
\hline P-value & 0.055 & 0.010 & $<0.001$ & $<0.001$ \\
\hline LSD & ns & 0.07 & 0.03 & 0.08 \\
\hline \multicolumn{5}{|c|}{ Residual fertilizer } \\
\hline NK & 2.90 & 2.36 & 1.47 & 1.40 \\
\hline NP & 2.98 & 2.37 & 1.55 & 1.42 \\
\hline PK & 2.39 & 2.29 & 1.32 & 1.30 \\
\hline NPK & 3.17 & 2.74 & 1.67 & 1.49 \\
\hline $\mathrm{NPK}+\mathrm{ZnBMgCaS}$ & 3.82 & 3.14 & 1.73 & 1.83 \\
\hline $\mathrm{P}$-value & $<0.001$ & $<0.001$ & 0.034 & $<0.001$ \\
\hline LSD & 0.69 & 0.36 & 0.26 & 0.13 \\
\hline \multicolumn{5}{|c|}{ Tillage method $\times$ residual fertilizer } \\
\hline p-value & 0.064 & 0.059 & 0.067 & 0.086 \\
\hline LSD & ns & ns & ns & ns \\
\hline
\end{tabular}

DAE: Days after emergence; NT+CR: No-till with crop residues retention; CT-CR: Conventional tillage with no crop residues retention; NT: No-tillage; CT: Conventional tillage; CR: Crop residue; ns: Not significant

Table 3. Number of pods per plant and number of seeds per pod of the common bean as influenced by tillage methods and residual fertilizers at Embu and Kirinyaga trial sites during 2014/2015 short rains season.

\begin{tabular}{|c|c|c|c|c|}
\hline \multirow{2}{*}{ Treatment } & \multicolumn{2}{|c|}{ Pods per plant } & \multicolumn{2}{|c|}{ Seeds per pod } \\
\hline & Embu site & Kirinyaga site & Embu site & Kirinyaga site \\
\hline \multicolumn{5}{|c|}{ Tillage method } \\
\hline $\mathrm{NT}+\mathrm{CR}$ & 15.60 & 13.27 & 4.80 & 4.93 \\
\hline CT-CR & 13.00 & 12.20 & 4.00 & 4.87 \\
\hline P-value & $<0.001$ & 0.045 & $<0.001$ & 0.071 \\
\hline LSD & 1.18 & 0.95 & 0.28 & ns \\
\hline \multicolumn{5}{|c|}{ Residual fertilizer } \\
\hline NK & 12.00 & 10.83 & 4.33 & 4.83 \\
\hline NP & 13.67 & 11.50 & 4.50 & 5.00 \\
\hline $\mathrm{PK}$ & 14.67 & 12.67 & 3.84 & 4.67 \\
\hline NPK & 15.50 & 12.67 & 4.50 & 5.00 \\
\hline $\mathrm{NPK}+\mathrm{ZnBMgCaS}$ & 15.67 & 16.00 & 4.83 & 5.00 \\
\hline P-value & $<0.001$ & $<0.001$ & $<0.001$ & 0.092 \\
\hline LSD & 1.87 & 1.51 & 0.45 & ns \\
\hline \multicolumn{5}{|c|}{ Interaction: Tillage method $\times$ residual fertilizer } \\
\hline P-value & 0.061 & 0.114 & 0.057 & 0.099 \\
\hline LSD & ns & ns & ns & ns \\
\hline
\end{tabular}

DAE: Days after emergence; NT+CR: No-till with crop residues retention; CT-CR: Conventional tillage with no crop residues retention; NT: No-tillage; CT: Conventional tillage; CR: Crop residue; ns: Not significant 
Table 4. Common bean 1000-seed weight and grain yield as influenced by tillage methods and residual fertilizers at Embu and Kirinyaga trial sites during 2014/2015 short rains season.

\begin{tabular}{|c|c|c|c|c|}
\hline \multirow{2}{*}{ Treatment } & \multicolumn{2}{|c|}{ 1000-seed weight $(\mathrm{g})$} & \multicolumn{2}{|c|}{ Grain yield $\left(\mathrm{t} \mathrm{ha}^{-1}\right)$} \\
\hline & Embu site & Kirinyaga site & Embu site & Kirinyaga site \\
\hline \multicolumn{5}{|c|}{ Tillage system } \\
\hline $\mathrm{NT}+\mathrm{CR}$ & 359 & 302 & 1.59 & 1.21 \\
\hline CT-CR & 334 & 297 & 1.39 & 1.07 \\
\hline P-value & $<0.001$ & 0.192 & $<0.001$ & $<0.001$ \\
\hline LSD & 10 & ns & 0.12 & 0.09 \\
\hline \multicolumn{5}{|c|}{ Residual fertilizers } \\
\hline NK & 344 & 293 & 1.39 & 1.01 \\
\hline NP & 344 & 302 & 1.40 & 1.03 \\
\hline PK & 337 & 282 & 1.23 & 0.87 \\
\hline NPK & 346 & 304 & 1.60 & 1.20 \\
\hline $\mathrm{NPK}+\mathrm{ZnBMgCaS}$ & 360 & 315 & 1.83 & 1.58 \\
\hline $\mathrm{P}$-value & 0.021 & 0.045 & $<0.001$ & $<0.001$ \\
\hline LSD & 16 & 19 & 0.20 & 0.14 \\
\hline \multicolumn{5}{|c|}{ Interaction: Tillage method $\times$ residual fertilizer } \\
\hline P-value & 0.084 & 0.155 & 0.055 & 0.061 \\
\hline LSD & ns & ns & ns & ns \\
\hline
\end{tabular}

DAE: Days after emergence; NT+CR: No-till with crop residues retention; CT-CR: Conventional tillage with no crop residues retention; NT: No-tillage; CT: Conventional tillage; CR: Crop residue; ns: Not significant

Table 5. Effect of tillage methods and residual fertilizers on grain to stover ratio and harvest index of dry bean at Embu and Kirinyaga trial sites during 2014/2015 short rains season.

\begin{tabular}{|c|c|c|c|c|}
\hline \multirow{2}{*}{ Treatment } & \multicolumn{2}{|c|}{ Grain to stover ratio } & \multicolumn{2}{|c|}{ Harvest index } \\
\hline & Embu & Kirinyaga & Embu & Kirinyaga \\
\hline \multicolumn{5}{|c|}{ Tillage method } \\
\hline $\mathrm{NT}+\mathrm{CR}$ & 0.927 & 0.762 & 0.481 & 0.431 \\
\hline CT-CR & 0.998 & 0.758 & 0.499 & 0.429 \\
\hline $\mathrm{P}$-value & 0.149 & 0.136 & $<0.001$ & 0.284 \\
\hline LSD & ns & ns & 0.015 & ns \\
\hline \multicolumn{5}{|c|}{ Residual fertilizers } \\
\hline NK & 0.947 & 0.629 & 0.486 & 0.386 \\
\hline NP & 0.907 & 0.710 & 0.475 & 0.414 \\
\hline PK & 0.937 & 0.792 & 0.483 & 0.442 \\
\hline NPK & 0.954 & 0.801 & 0.488 & 0.445 \\
\hline $\mathrm{NPK}+\mathrm{ZnBMgCaS}$ & 1.068 & 0.869 & 0.516 & 0.465 \\
\hline P-value & 0.093 & 0.088 & $<0.001$ & 0.031 \\
\hline LSD & ns & ns & 0.025 & 0.040 \\
\hline \multicolumn{5}{|c|}{ Interaction: Tillage method $\times$ residual fertilizer } \\
\hline P-value & 0.359 & 0.201 & 0.059 & 0.256 \\
\hline LSD & ns & ns & ns & ns \\
\hline
\end{tabular}

DAE: Days after emergence; NT+CR: No-till with crop residues retention; CT-CR: Conventional tillage with no crop residues retention; NT: No-tillage; CT: Conventional tillage; CR: Crop residue; ns: Not significant

Effect of Tillage Method and Residual Fertilizer on Grain to Stover Ratio and Harvest Index

In both sites, the tillage method had no significant effect on dry bean grain to stover ratio (Table 5). The tillage method had a significant effect on the dry bean harvest index in Embu site but had no effect on this parameter in Kirinyaga. The CT-CR tillage system produced a higher harvest index (0.499) than NT+CR tillage system (0.481) (Table 5). The residual fertilizers had significant effect on the harvest index in both sites. In Embu site, $\mathrm{NPK}+\mathrm{ZnBMgCaS}$ had significantly higher harvest index than all the other treatments, whose harvest indices were similar. In Kirinyaga, $\mathrm{NPK}+\mathrm{ZnBMgCaS}$ resulted in higher harvest indices than NK and NP. No significant differences were recorded between NK and NP, among NP, PK, and NPK and among PK, NPK, and $\mathrm{NPK}+\mathrm{ZnBMgCaS}$ residual fertilizer. The interaction between tillage method and residual fertilizer nutrient had no significant effect on the harvest index. Grain stover ratio varied from 0.758 (Kirinyaga) to 0.998 (Embu).

\section{Discussion}

\section{Effect of Tillage Method on Soil Water Retention, Common Bean Biomass, Yield Components, and Grain Yield}

The combination of no-till with residue retention $(\mathrm{NT}+\mathrm{CR})(\mathrm{NT}=$ No-tillage$; \mathrm{CT}=$ Conventional tillage $; \mathrm{CR}$ $=$ Crop residue) recorded higher dry bean shoot biomass (at 60 days after emergence), stover yield, number of pods per plant, number of seeds per pod, 1000-seed weight, grain yield and harvest indices than conventional tillage plot with no residue retention (CT-CR). These findings are in resonance with Abdul-Baki and Teasdale (1997) who 
observed higher snap bean yields under no-till with hairy vetch mulch than under conventional tillage. Micheni et al. (2014) reported higher grain yield of dry bean in Embu region under zero tillage than under conventional tillage. During a trial to determine the effects of tillage on the yield of pea and chickpea, Ruisi et al. (2012) also reported significantly higher yield under no-till plots than under conventional tillage. The better performance of dry bean under NT+CR system than under CT-CR system may be associated with the higher moisture retained during the production period (Table 2). Other researchers have also reported better soil water conservation and yields under crop residue cover and no-till systems (Mupangwa et al.2012; Reddy et al. 2013; Nyawade et al. 2019). Also, some of these residues may have undergone decomposition releasing nutrients for bean growth and yield production. Reduced disturbance of land under no-till may have resulted in improved soil physical, chemical and biological qualities for better crop production (Sommer et al., 2014). Higher Meloidogyne spp. incidence observed under CTCR (range 3-4) than under NT+CR (range 2-3), may have also affected crop anchorage and hindered water and nutrient absorption, hence leading to lower yield in the former tillage system than in the latter, as reported by Agu (2008). Crop residue retention and reduced tillage have been reported to diversify the rage of food sources and prove habitat for Meloidogyne spp. thereby diverting their attention from common bean infection (Mendoza et al., 2008). Despite high yield performance of dry bean under no-till with crop residue retention, these yields were lower than the performance of this bean variety at the research station but much higher than yields obtained in farmers' fields in the study region. Farmers are reported to achieve average bean yields of less than $1 \mathrm{t} \mathrm{ha}^{-1}$ (Monyo et al., 2013), however, the potential yield of Roscoco, EM-bean 14 variety is about $5 \mathrm{t} \mathrm{ha}^{-1}$ (KALRO-Embu website). The dry bean harvest indices varied between 0.43 and 0.50 . These harvest indices are in the range of other previous studies; Vieira et al. (1973) found a range of 0.39 to 0.58 and Scully and Wallace (1990) found a range of 0.12 to 0.65 among accessions of dry bean studied.

Effect of Residual Fertilizer on Biomass, Yield Components and Grain Yield of Dry Bean

The PK residual treatment resulted in lower biomass (at 60 DAE), stover dry weight, number of seeds, 1000-seed weight and grain yields than the other treatments. This low bean performance due to $\mathrm{N}$ omission shows the importance of the nutrient in dry bean production. Otieno et al. (2009) observed a significant increase in dry bean biomass due to $\mathrm{N}$ addition. This is because of the pivotal roles played by $\mathrm{N}$ in plants' biochemical and physiological processes like photosynthesis and protein formation (Fageria, 2014). Residual N nutrient has been reported to increase dry matter and total $\mathrm{N}$ uptake of wheat (Sieling et al. 2006).

Application of fertilizers with a broad range of nutrients recorded a higher range of growth and yield than fertilizers with one nutrient. Generally, combined application of $\mathrm{N}$, $\mathrm{P}$, and $\mathrm{K}$ recorded higher biomass production, number of pods per plant, number of seeds per pod, 1000-seed dry weights and dry grain yields than when only NP, NK or PK was applied. These findings are in agreement with Mananu et al. (2012) who reported increased shoot dry weights due to combined application of $\mathrm{N}$ and $\mathrm{P}$ and $\mathrm{N}, \mathrm{P}$ and $\mathrm{K}$ than when $\mathrm{N}$ was applied in snap bean alone. Arjumand et al., (2013) also observed taller plants and a higher number of branches per plant and number of leaves per plant due to combined application of N, P and $\mathrm{K}$ than when either of the nutrients was applied singly. They further observed that application of $\mathrm{Zn}, \mathrm{Ca}, \mathrm{Mg}, \mathrm{B}$ and $\mathrm{S}$ nutrients together with NPK resulted in the best performance of dry bean in shoot biomass and grain yields. Abid et al. (2013) showed that the residual effect of zinc significantly increased wheat and cotton yield just as the plots that had continued application of these nutrients. Nitrogen, phosphorus, and potassium nutrients are essential nutrients in photosynthesis, roots development, environmental stress resistance, energy transfer, enzyme function, and general vegetative growth and general protein formation (Hüttemann, et al., 2007; Pretorius, 2009). Therefore, when these nutrients were applied together, they may have brought the synergy that resulted in increased biomass, stover production, yield components, and grain yields. Similar observations were also made by Sieling et al. (2006) on residual N effect on growth and yield of oilseed rape, wheat, and barley after three seasons. In contrast to this trial, a study showed that residual $\mathrm{P}$ from long-term $\mathrm{P}$ fertilization was not sufficient alone to provide all the $\mathrm{P}$ requirements of barley grown in a monoculture system when $\mathrm{P}$ fertilization was discontinued after 20 years of application (Karamanos et al., 2007).

Secondary macronutrients and essential micronutrients play an important role in plant growth and production. From this trial, $\mathrm{Zn}, \mathrm{Ca}, \mathrm{Mg}, \mathrm{B}$ and $\mathrm{S}$ may have played important roles in dry bean growth and development resulting in significant increases in biomass at 60 DAE, stover, number of pods and grain yield. The combined application of $\mathrm{B}, \mathrm{Mo}$, and $\mathrm{Zn}$ has been reported to increase dry bean plant height, number of branches and seeds per pod (Rahman et al., 2014). This is because micronutrients play key roles in legume growth and grain yield production (Fageria, 2014). For instance, boron is involved in pollen germination, pollen tube formation and seed formation (Fageria and Gheyi, 1999), thereby increasing the number of seeds per pod and grain yield (Kaur and Nelson, 2015) while $\mathrm{Ca}$ and $\mathrm{Mg}$ enhance ion uptake and balance, plant vigour and stiffness of straw (Fageria, 2009). These nutrients also may have boosted the photosynthetic process and translocation of photosynthates to the seeds (Zeidan et al., 2006). This may explain higher 1000-seed weights and grain yields recorded due to $\mathrm{NPK}+\mathrm{ZnBMgCaS}$ residual nutrients than all other treatments.

Dry bean production in Kenya often involves no fertilizer addition and this result in low bean production by small-scale farmers every season. With just the residual nutrients from the previous season of maize production, farmers can increase their grain yields significantly from less than $1 \mathrm{t} \mathrm{ha}^{-1}$ as reported by most researchers to about $1.8 \mathrm{t} \mathrm{ha}^{-1}$ as observed in this study. Adoption of the practice could improve farmers' economic stability, as yields are increased without the addition of fertilizers. Production of dry bean as a rotational crop on residual fertilizers ensures maximum utilization of applied nutrients during maize production and improvement in soil fertility through BNF and organic matter- though was not tested, this has been reported by several researchers. 


\section{Conclusion and Recommendations}

This study found out that no-till with crop residues retention has the potential to increase bean productivity for better food production. No-till combined with crop residue retention significantly reduced water loss there increasing plant available water for better growth. Also, though was shallowly covered, a combination of no-till with crop residue retention has shown the potential to reduce the effects of nematode on common bean. The residual fertilizers significantly increased dry bean yield irrespective of the tillage method. With the application of a broad range of nutrients, farmers are likely to increase plant growth and yield relative to the application of single nutrients. From this trial, $\mathrm{N}$ was noted to be the most limiting nutrient followed by phosphorus and then potassium. Application of micronutrients increased yields, but not by a similar margin as the three primary macronutrients. This research, however, failed to separate the effects of individual micronutrient.

From this work, we recommend the following;

- $\quad$ Further multi-season and site trials to be carried out to assess the long-term sustainability of the system in bean production.

- The response due to individual micronutrients should be assessed for better recommendation in term of which micronutrients worth including in the fertilizer blends.

- Intensive assessment and characterization of the nematode species and the effect of tillage method need to be carried out for better understanding and appropriate control measure recommendation.

- Intensive assessment into the farmers' possibilities of abandoning the traditional practice of removing crop residue for fodder and fuel to allow for build-up of mulch and organic matter.

\section{Acknowledgements}

The authors appreciate the financial support offered by the International Plant Nutrition Institute (IPNI) and the International Maize and Wheat Improvement Centre (CIMMYT) and the technical and professional guidance offered by College of Agriculture and Veterinary Sciences, University of Nairobi.

\section{Conflicts of Interest}

The authors declare no conflict of interest.

\section{References}

Abate T, Alene AD, Bergvinson D, Shiferaw B, Silim S, Orr A and Asfaw S. 2012. Tropical grain legumes in Africa and South Asia: knowledge and opportunities. Nairobi, Kenya: International Crops Research Institute for the Semi-Arid Tropics. 112 pp. Accessed on $6^{\text {th }}$ December 2019 from http://oar.icrisat.org/5680/.

Abdul-Baki AA, Teasdale JR. 1997. Snap bean production in conventional tillage and in no-till hairy vetch mulch. Horticultural Science, 32(7): 1191-1193.

Agu CM. 2008. Effect of organic manure types on Root-gall Nematode disease and African yam bean yield. Agriculture, 3(1): 14-16.
Arjumand SS, Ananth NB, and Puttaiah E. 2013. Effectiveness of farmyard manure, poultry manure, and fertilizer - NPK on the growth parameters of French bean (Phaseolus vulgaris) in Shimoga, Karnataka, 1(1): 31-35.

Monyo E, Boukar O, Ntare B. 2013. Cowpea, groundnut intensifying in Mali: Bulletin of the Tropical Legumes ii project, pp. 1-12. Accessed on $6^{\text {th }}$ December 2019 from http://www.icrisat.org/tropicallegumesII

Labarta R. 2013. Common bean, cassava and tropical forages: The impacts of CIAT's collaborative research. Cali, Colombia: International Center for Tropical Agriculture (CIAT). Accessed on $6^{\text {th }}$ December 2019 from http://hdl.handle.net/10568/51592

Fageria NK, Gheyi HR. 1999. Efficient Crop Production. Campina Grande, Brazil: Federal University of Paraiba In FAGERIA N.K. 2009. The Use of Nutrient in Crops Plant. CRC Press Taylor and Francis Group, Boca Raton London New York. $135 \mathrm{p}$

Fageria NK, Baligar VC. 2009. Response of common bean, upland rice, corn, wheat, and soybean to soil fertility of an Oxisol. Journal of Plant Nutrition, 20: 1279-1289.

Fageria NK. 2014. The use of nutrients in crop plants. CRC Press Taylor \& Francis Group.

Gowing JW, Palmer M. 2008. Sustainable agricultural development in subSaharan Africa: The case for a paradigm shift in land husbandry. Soil Use and Management, 24(1): 92-99.

Hobbs PR, Sayre K, Gupta R. 2008. The role of conservation agriculture in sustainable agriculture. Philosophical Transactions of the Royal Society B: Biological Sciences, 363(1491): 543-555.

Hüttemann M, Lee I, Samavati L, Yu H, Doan JW. 2007. Regulation of mitochondrial oxidative phospho-rylation through cell signaling. Biochimica et Biophysica Acta (BBA)-Molecular Cell Research Journal, 1773: 1701-1720.

Jaetzold R, Schmidt H, Hornetz B, Shisanya CA. 2006. Farm Management Handbook of Kenya. Natural Conditions and Farm Information, $2^{\text {nd }}$ edition, vol. 11/C. Ministry of Agriculture/GTZ, Nairobi, Kenya (Eastern Province).

Jaetzold R. 2006. Farm Management Handbook of Kenya Vol. II $2^{\text {nd }}$ edition. Part C, East Kenya, Subpart C1, Eastern Province. Ministry of Agriculture, Nairobi Kenya.

Karamanos RE, Harapiak JT, Kruger GA. 2007. Long-term phosphorus fertilization effects on crop yields and soil phosphorus. Better Crops, 91. (2): 25-27.

Katungi E, Farrow A, Chianu J, Sperling L, Beebe S. 2009. Common bean in Eastern and Southern Africa: a situation and outlook analysis. International Centre for Tropical Agriculture, 61.

Kihara J, Martius C, Bationo A, Vlek PLG. 2011. Effects of tillage and crop residue application on soybean nitrogen fixation in a tropical ferrasol. Journal of Agriculture, 1(1): 22-37.

Klute A. 1986. Water Retention- Laboratory Methods. In: Methods of Soil Analysis, 528 Part 1. Physical and Mineralogical Methods. 2nd ed. Agronomy Monographs, No. 529 9. Klute, A. (Eds.), American Society of Agronomy and Soil Science Society of 530 America, Madison, Wisconsin, pp. 635-662.

Liebman M, Drummond FA, Corson S, Zhang J. 1996. Tillage and crop rotation effects on weed dynamics in potato production systems. Agronomy Journal, 88: 18-26.

Lu M, Yang Y, Luo Y, Fang C, Zhou X, Chen J, Yang X, Li B. 2011. Responses of ecosystem nitrogen cycle to nitrogen addition: a meta-analysis. New Phytologist, 189: 1040-1050.

Machado RMA, Bryla DR, Verissimo ML, Sena AM, Oliveira MRG. 2008. Nitrogen requirements for growth and early fruit development of drip-irrigated processing tomato (Lycopersicon esculentum Mill.) in Portugal. Journal of Food, Agriculture and Environment, 6(3-4): 215-218. 
Marongwe LS, Kwazira K, Jenrich M, Thierfelder C, Kassam A, Friedrich T. 2011. An African success: the case of conservation agriculture in Zimbabwe. International journal of agricultural sustainability, 9(1), 153-161.

Mendoza RB., Franti TG, Doran JW, Powers TO, Zanner CW. 2008. Tillage effects on soil quality indicators and nematode abundance in loessial soil under long-term no-till production. Communications in Soil Science and Plant Analysis, 39(1314): 2169-2190.

Micheni A, Ouma J, Kanampiu F, Mburu D, Mugai N. 2014. Maize-bean farming system under conservation agriculture: Assessing productivity and sustainability in Eastern Kenya, 2012-2014. Available at: http://www.ctic.org

Mupangwa W, Twomlow S, Walker S. 2012. Reduced tillage, mulching and rotational effects on maize (Zea mays L.) cowpea (Vigna unguiculata L. (Walp)) and sorghum (Sorghum bicolor L. (Moench)) yields under semi-arid conditions. Field Crops Research, 132: 139-148.

Nyawade SO, Gachene CK, Karanja NN, Gitari HI, SchulteGeldermann E, Parker ML. 2019. Controlling soil erosion in smallholder potato farming systems using legume intercrops. Geoderma Regional, 17, e00225.

Otieno PE, Muthomi JW, Chemining'wa GN, Nderitu JH. 2009. Effect of rhizobia inoculation, farmyard manure and nitrogen fertilizer on nodulation and yield of food grain legumes. Journal of Biological Sciences, 9(4): 326-332.

Otieno HMO. 2019. Pesticide training tool: A simplified guide for Agricultural Extension Officers and Farmers. Asian Journal of Research in Crop Science, 1-5.

Otieno HMO, Chemining'Wa GN, Zingore S 2018. Effect of farmyard manure, lime and inorganic fertilizer applications on soil $\mathrm{pH}$, nutrients uptake, growth and nodulation of soybean in acid soils of western Kenya. Journal of Agricultural Science, 10: 199-208.

Otieno HMO, Chemining'wa GN, Gachene CK, Zingore S. 2019. Economics of Maize and Bean Production: Why Farmers need to Shift to Conservation Agriculture for Sustainable Production. Turkish Journal of Agriculture-Food Science and Technology, 7(10): 1548-1553.

Pretorius H. 2009. The ability of a novel compound to enhance the effect of urea on nitrogen deficient tomatoes. University of the Free State, Bloemfontein.
Rahman IU, Afzal A, Iqbal Z, Ijaz F, Manan S, Ali A, Qadir G. 2014. Growth and yield of Phaseolus vulgaris as influenced by different nutrients treatment in Mansehra. International Journal of Agronomy and Agricultural Research, 4(3): 20-26.

Recha CW, Makokha GL, Traore PS, Shisanya C, Lodoun T, Sako A. 2012. Determination of seasonal rainfall variability, onset, and cessation in semi-arid Tharaka district, Kenya. Theoretical and Applied Climatology, 108: 479-494.

Reddy KN, Zablotowicz RM, Krutz LJ. 2013. Corn and soybean rotation under reduced tillage management: Impacts on soil properties, yield, and net return. American Journal of Plant Sciences, 4: 10-17.

Ruisi P, Giambalvo D, Miceli GD, Frenda AS, Saia S, Amato G. 2012. Tillage effects on yield and nitrogen fixation of legumes in Mediterranean conditions. Agronomy Journal, 104(5): 1459-1466.

Scully BT, Wallace DH. 1990. Variation in and relationship of biomass, growth rate, harvest index, and phenology to yield of common bean. Journal of American Society of Horticulture Sciences, 115: 218-225.

Sieling K, Brase T, Svib V. 2006. Residual effects of different N fertilizer treatments on growth $\mathrm{N}$ uptake and yield of oilseed rape, wheat, and barley. European Journal of Agronomy, 25: $40-48$.

Sieling K, Brase T, Svib V. 2006 Residual effects of different N fertilizer treatments on growth, $\mathrm{N}$ uptake and yield of oilseed rape, wheat, and barley. European Journal of Agronomy, 25(1): 40-48.

Sommer R, Piggin C, Feindel D, Ansar M, Delden L, Van Shimonaka K, Ryan J. 2014. Effects of zero tillage and residue retention on soil quality in the Mediterranean Region of Northern Syria. Open Journal of Soil Science, 4: 109-125.

Turner NC. 2004. Sustainable production of crops and pastures under drought in a Mediterranean environment. Annals of Applied Biology, 144(2): 139-147.

Vieira C, Santa Cecília FC, Sediyama CS. 1973. Índice de colheita de alguns cultivares de feijão (Phaseolus vulgaris L.). Review Ceres, 20: 120-128.

Voisin AS, Guéguen J, Huyghe C, Jeuffroy MH, Magrini MB, Meynard JM, Pelzer E. 2014. Legumes for feed, food, biomaterials and bioenergy in Europe: a review. Agronomy for Sustainable Development, 34(2): 361-380. 